\title{
Clinical Aspects of Central Obesity at a Public Clinic
}

\author{
Izabela Ferraz ${ }^{\mathrm{a}, \mathrm{b}, \mathrm{e}}$, Izabela Gelisk ${ }^{\mathrm{c}}$, Manuela Lima ${ }^{\mathrm{d}}$, Maria de Lourdes Silva ${ }^{\mathrm{b}}$, \\ Ana Marice Ladeia ${ }^{\mathrm{b}}$, Armenio Costa Guimaraes ${ }^{\mathrm{b}}$
}

\begin{abstract}
Background: The relation between central obesity epidemic and food consumption strategies has drawn attention towards understanding its complexity. The aim of our study is to evaluate clinical and nutritional aspects of women with central obesity in Salvador, Bahia.
\end{abstract}

Methods: The study was done in 89 adult women with waist circumference $>84 \mathrm{~cm}$ after individualized outpatient consultations for 48 months (2012 - 2015). Direct interviews were performed with the application of three $\mathrm{R} 24 \mathrm{~h}$ recalls to evaluation of food consumption in relation to macronutrients, fiber and energy. The biochemical variables were determined in the blood collected with a 12-h fasting period.

Results: There was a significant reduction in the waistline circumference baseline and final values, associated to a reduction in body fat percentage and a significant increase in body water. A significant reduction was observed in the consumption of carbohydrates in parallel to an increase in the consumption of fibers and 55 times in the percentage of consumption of lipids, in addition to a significant reduction in the baseline and final values of glycosylated hemoglobin, fasting glycemia and low-density lipoprotein cholesterol (LDL-C).

Conclusions: It was observed that outpatient care with emphasis in the quality of the diet was capable of reducing anthropometric and clinical variables attributed to the development of illnesses associated with central obesity.

Keywords: Women; Central obesity; Low income; Dietary intake; Food consumption

Manuscript submitted June 2, 2018, accepted June 13, 2018

${ }^{a}$ Human Medicine and Health, Medicine and Human Health by the Bahian School of Medicine and Public Health (EBMSP), Bahia, Brazil

${ }^{b}$ Multidisciplinary Teaching Clinic for Overweight/Obese Patients (PEPE PROJECT) at EBMSP, Bahia, Brazil

${ }^{c}$ Nutrition and Health, Federal University of Bahia (UFBA), Salvador, Brazil ${ }^{\mathrm{d}}$ Medicine and Human Health by the Bahian School of Medicine and Public Health (EBMSP), Bahia, Brazil

${ }^{\mathrm{e}}$ Corresponding Author: Izabela Ferraz, Multidisciplinary Teaching Clinic for Overweight/Obese Patients at EBMSP (Escola Bahiana de Medicina e Saude Publica), Av. Dom Joao VI, 274, Brotas, Salvador,

Brazil. Email: izabelaferraz2117@gmail.com

doi: https://doi.org/10.14740/jem516w

\section{Introduction}

Central obesity is characterized by the increase in waist circumference (WC) due to the accumulation of body fat in the abdomen and is associated to increased risk towards the development of hypertension, dyslipidemia and diabetes, causing an increase in the risk of morbidity and mortality from metabolic and cardiovascular diseases [1]. Considering the epidemic of central obesity in the low income Brazilian population, knowledge in relation to the quantity and mainly to the quality of the food consumed is necessary for an adequate nutritional approach [2].

At present, countless discussions address dietary issues and their relation as health indicators, raising the interest of understanding the magnitude of the problem, mainly in the northeastern region of Brazil, where a high prevalence is presented for low income women, which is apparently a paradoxical fact [3].

In view of the relevance of the issue and given the lack of information in the city of Salvador, the objective of this paper is to evaluate the clinical and nutritional aspects of women with central obesity treated at an Outpatient Teaching Clinic for Obese Patients at Escola Bahiana de Medicina e Saude Publica, in Salvador, Bahia.

\section{Materials and Methods}

This is a prospective clinical trial of obese women, treated at an Outpatient Teaching Clinic at Escola Bahiana de Medicina e Saude Publica, EBMSP, as part of the research project on People with Excess Weight (PEPE), which is an interdisciplinary, multiprofessional project for the healthcare of patients attended by the National Health Service (SUS).

All of the participants selected for the present study had individual attendance, as outpatients, for 48 months (2012 2015). The sample was made up of women from low socioeconomic classes $\mathrm{C}, \mathrm{D}$ and $\mathrm{E}$, classified in accordance with family income class $\mathrm{E}$ (up to 2 minimum wages), class $\mathrm{D}$ (2 to 4 minimum wages) and class $\mathrm{C}$ (4 to 10 minimum wages), in line with the classification criteria of the Instituto Brasileiro de Geografia e Estatistica (IBGE) [4] (Brazilian Institute of Geography and Statistics), and who attended the quarterly consultations, with ages above 18 years, body mass index (BMI) $>25 \mathrm{~kg} / \mathrm{m}^{2}$ and WC $>84 \mathrm{~cm}$ [5]. Women with difficulty of expression, pregnant or nursing, using chemotherapy drugs, anorexic agents/ 
appetite suppressants or psychiatric disorders were excluded.

Data collection was performed after the signature of the written informed consent form, using a structured questionnaire to meet the objectives of outpatient care. The studied variables included age (years), skin color (self-referred), schooling and income. The weight was measured $(\mathrm{kg})$ and body composition (lean mass, fat mass and percentage of body fat) using bioimpedance scales (equipment InBody 520, Biospace $($ ), with a capacity of up to $250 \mathrm{~kg}$. Height was measured using a portable stadiometer (Altura Exata TBW, Sao Paulo, Brazil) limited to $2.1 \mathrm{~m}$ and precision of $1.0 \mathrm{~cm}$; the individual remained facing backwards, in an erect position, barefoot, with feet parallel to each other, heels joined, calves, hips, shoulders, scapular region and head against the stadiometer, with the head at the Frankfurt horizontal plane [6]. The BMI represents the ratio of the weight by the height squared $(\mathrm{BMI}=$ weight $(\mathrm{kg}) /$ height $\left(\mathrm{m}^{2}\right)$ ). The BMI of $25 \mathrm{~kg} / \mathrm{m}^{2}$ was used as the lowest limit for excess weight, used to calculate the percentage of BMI loss (\%WL) [5]. The standard weight was considered the weight on the first evaluation and for the calculation of the ideal weight BMI $21.5 \mathrm{~kg} / \mathrm{m}^{2}$ was defined [6]. Weight loss (\%WL) was assessed and excess weight loss (\%EWL) of overweight/obese patients, using the following formula: $\times 100$

$\% \mathrm{WL}=(($ iniital weight - present weight $) /$ initial weight $)$

$\% \mathrm{EWL}=(($ initial weight - present weight $) /$ initial weight - ideal weight $) \times 100$

WC was measured using an inelastic tape measure, 0.5 $\mathrm{cm}$ scales, horizontal plane, having as reference the midpoint located between the last rib and the right iliac crest. Classification as increased when equal to or greater than $84 \mathrm{~cm}$ according to the cut-off point indicated by Barbosa et al [7].

The biochemical variables were determined in blood collected after a 12-h fast. Borderline values used for classification of alterations were: 1) Fasting blood glucose levels considered as elevated when superior to $100 \mathrm{mg} / \mathrm{dL}$; 2) Alterations in the lipid profile were classified as hypercholesterolemia (total cholesterol $(\mathrm{TC})>200 \mathrm{mg} / \mathrm{dL}$ ), hypertriglyceridemia (triglycerides, $\geq 150 \mathrm{mg} / \mathrm{dL}$ ), low level of HDL-C when $<40 \mathrm{mg} /$ $\mathrm{dL}$ and high level of LDL-C $>100 \mathrm{mg} / \mathrm{dL}$ [8].

For assessment of dietary intake, three $24 \mathrm{~h}$ (R24h) recalls were used, two collected during the week (Tuesday and Thursday) and another on Sunday, with 7-day interval to contemplate the dietary variations that could occur during the week, describing in an accurate manner the consumption, types of meals, preparation, household measures, quantities and times of consumption, including the ingestion of macronutrients (carbohydrates, lipids, protein), dietary fibers and micronutrients (vitamins and minerals). The data obtained were converted into energy and nutrients using the Nutwin ${ }^{\circledR}$ program [9], performed through double entry to certify that the data were included correctly. Support tables were used [10, 11] for the inclusion of food or ingredients unavailable in the program [9]. Nutrients were adjusted by energy according to the residual method, to eliminate the influence of calories in the consumption of nutrients, whereby the calories are considered as independent variables and nutrients as dependent variables, accordingly the "adjusted" nutrient represents the actual value of each ingested nutrient without the influence of total energy consumed. The consumption of fibers was assessed according to the recommendations established by the Dietary Reference Intakes (DRI) Committee, in which women should consume a minimum of $21 \mathrm{~g}$ of fibers/day [12]. The criteria for the consumption of fat was established in accordance with the Sociedade Brasileira de Cardiologia (Brazilian Cardiology Society) [13] in consonance with the recommendations of the National Heart Lung and Blood Institute of the USA [14], which proposes a consumption of saturated fat of less than or equal to $7 \%$ of total daily energy consumption, lower than or equal to $10 \%$ of the total daily consumption of polyunsaturated fat and lower than or equal to $20 \%$ of the daily consumption of monounsaturated fat. The daily ingestion value was compared to the total energy expenditure (TEE) obtained using the DRI formula for gender, age and physical activity.

Nutritional guidance was performed individually and involved the adequate form of preparation and consumption, the importance of macro- and micronutrients, as well as stimulating the creation of new eating habits.

For the purpose of analysis, data were initially organized on Excel worksheets, with double entries. Subsequently, for statistical analysis, exported to the SPSS program, version 18.0 [15].

The verification of the normal distribution of data was performed using the Kolmogorov-Smirnov test, the comparison of the mean values was made by means of the paired Student's $t$-test, and associations through the Chi-square test, with a confidence level of $\mathrm{P}<0.05$ and confidence interval of $95 \%$. For energy and nutrient consumption estimates, the Nutwin $\AA$, Version 1.5 software for nutritional assessment was used [9].

\section{Results}

Table 1 demonstrates the demographic and socioeconomic profile of 89 women with central obesity. Average age was of $48.5 \pm 12.4$ years, with $51(57.3 \%)$ between 40 - 59 years and $11(12.3 \%) \geq 60$ years. Predominance was for skin color brown, 44 (48.8\%), followed by black, 37 (33.5\%), and a minority of white, $11(12.5 \%)$. Schooling levels of the majority were incomplete secondary school, $49(54.4 \%)$, followed by incomplete elementary school, 35 (38.8\%). Family income was predominantly of 1.5 - 2.5 minimum wages, 57 (64\%), followed by under 1.5 minimum wage for $23(25.8 \%)$.

In Table 2 average daily consumption of energy is presented, calculated from the $24-\mathrm{h}$ recalls, including carbohydrates, proteins, total lipids and fibers. It was verified that there was no significant difference between energetic ingestion, initial and final $(\mathrm{P}>0.05)$. Nevertheless, in relation to macronutrients, a significant decrease was observed in the consumption of carbohydrates $(\mathrm{P}=0.002)$ in parallel to an increase in the consumption of fibers $(\mathrm{P}=0.04)$. On the other hand, it should be observed that despite not having evidenced a significant difference between the baseline and final values in the total consumption of lipids $(\mathrm{P}=0.74)$, the percentage of consumption in the recommended range of 15 to $30 \%$ of total calories increased 5.5 times, $12 \mathrm{~g}(13.48 \%)$ versus $65 \mathrm{~g}(73.86 \%)$.

Table 3 presents the result of initial anthropometric and metabolic data and after 48 months of periodical, regular nutri- 
Table 1. Demographic and Economic Profile of Women With Central Obesity Treated at the EWLEa Project at EBMSPb, in Salvador, Bahia $(\mathrm{N}=89)$

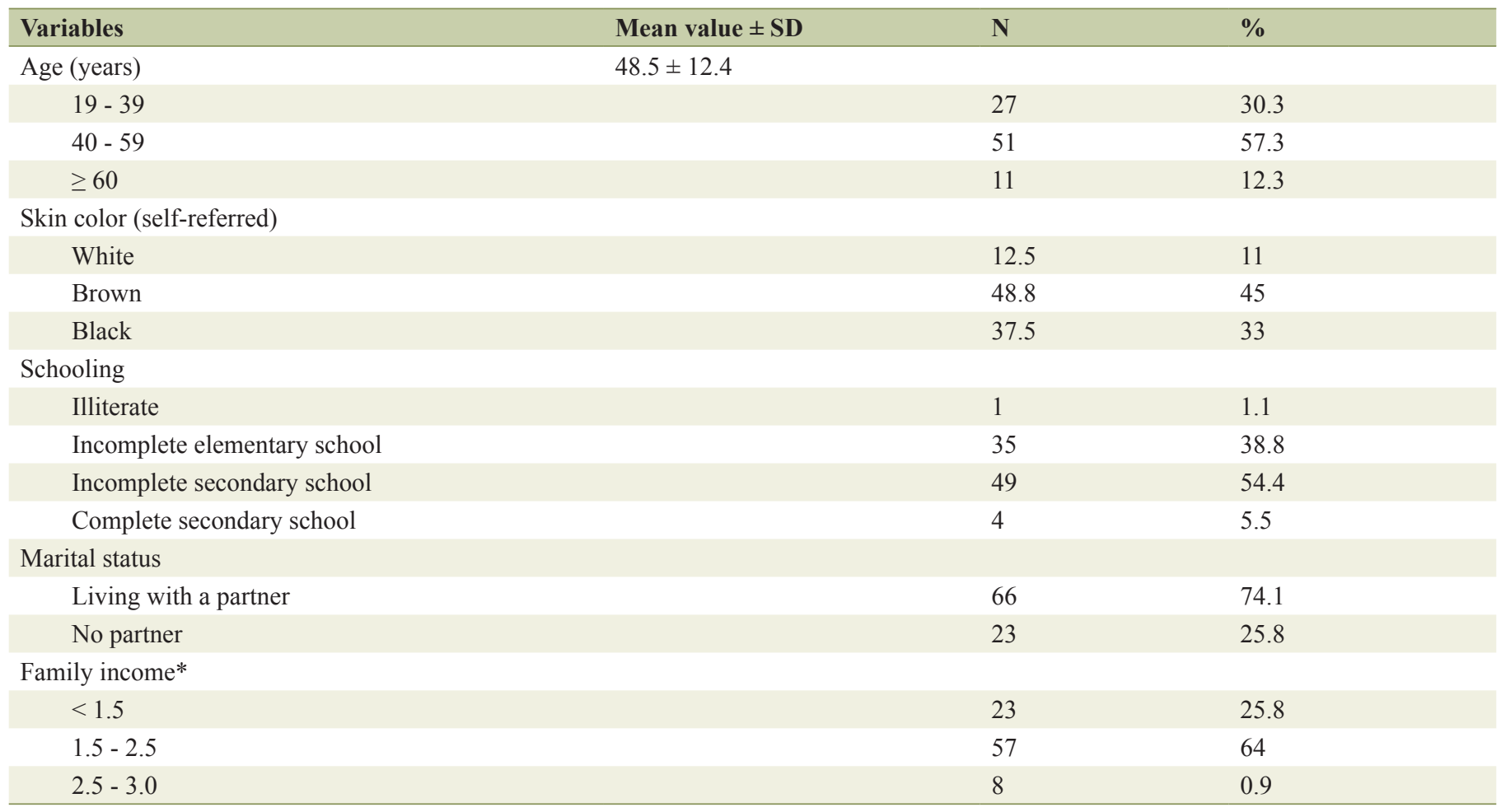

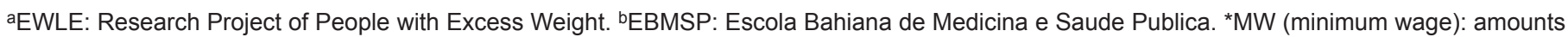
expressed in Brazilian reais, prevailing in 2015 (R\$ 788.00). N: number of participants.

Table 2. Results After Accompaniment of Quarterly Outpatient Nutritional Intervention* for 48 months, of Daily Consumption of Macronutrients, Fibers and Energy in Women With Central Obesity Treated at the EWLE ${ }^{a}$ Project at EBMSPb, in Salvador, Bahia $(\mathrm{N}=89)$

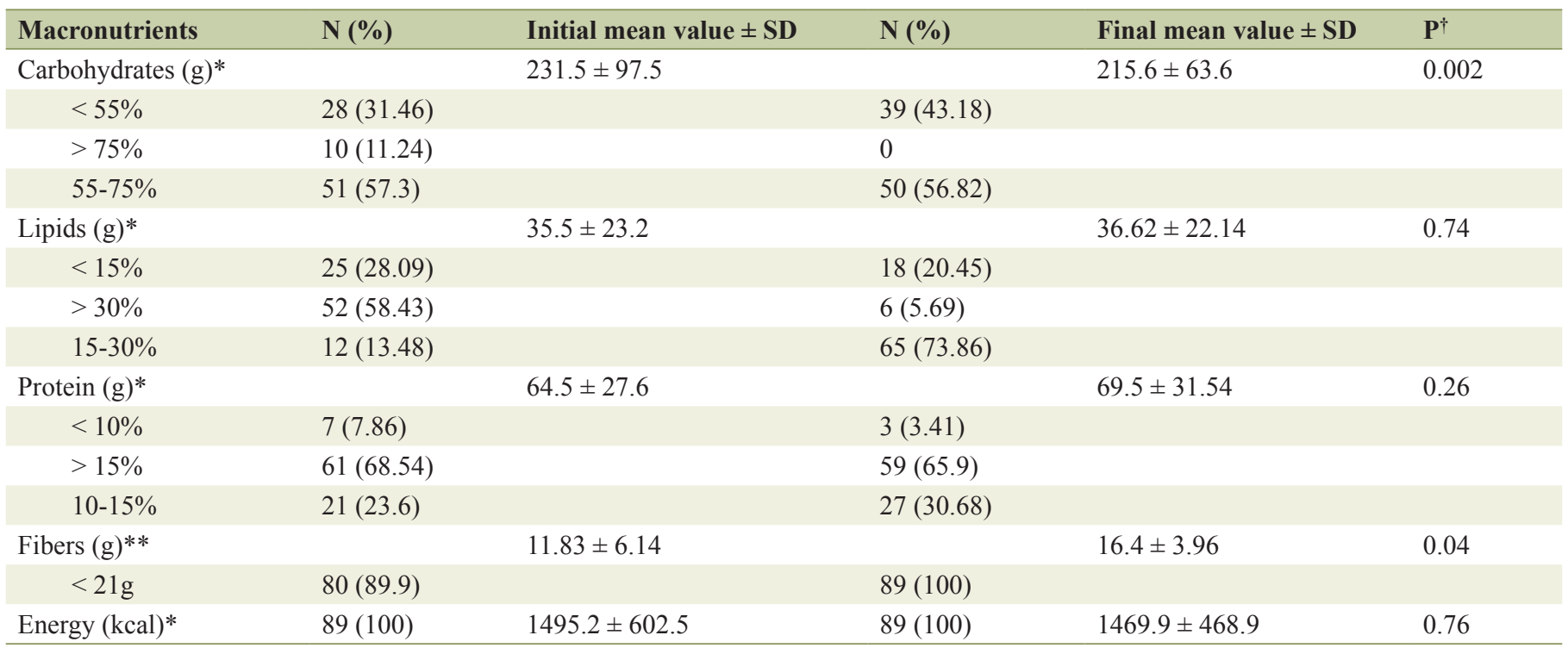

aEWLE: Research Project of People with Excess Weight. ${ }^{b} E B M S P$ : Escola Bahiana de Medicina e Saude Publica. ${ }^{\dagger} P$ values obtained through the comparison of initial and final data by means of the Student's $t$-test. Statistical significance level established at $P<0.05$. ${ }^{*}$ Recommended values of macronutrients for a balanced diet. **Minimum daily recommendation of fibers in accordance with the Sociedade Brasileira de Cardiologia SBC (Brazilian Society of Cardiology). 
Table 3. Anthropometric Data, Body Composition, Biochemical and Baseline Metabolic Rates of Women With Central Obesity Treated at the EWLE ${ }^{a}$ Project at EBMSP ${ }^{b}$, in Salvador, Bahia $(\mathrm{N}=89)$

\begin{tabular}{llllll} 
Variables & Baseline mean value \pm SD & Final mean value \pm SD & P $^{*}$ & Variables & Mean value \pm SD \\
\hline Weight $(\mathrm{kg})$ & $85 \pm 15.1$ & $85.46 \pm 16.4$ & 0.86 & \% Weight loss $($ WL $)$ & $1.06 \pm 6.4$ \\
BMI $\left(\mathrm{kg} / \mathrm{m}^{2}\right)$ & $34.2 \pm 5.5$ & $34.3 \pm 5.8$ & 0.92 & \% Excess weight loss $(\mathrm{EWL})$ & $4.09 \pm 21.8$ \\
WC $(\mathrm{cm})$ & $106 \pm 12.5$ & $100.2 \pm 11.38$ & 0.003 & \% BMI loss & $1.06 \pm 6.5$ \\
Body fat $(\%)$ & $43.2 \pm 7.7$ & $40.9 \pm 6.4$ & 0.04 & Ideal weight $(\mathrm{IW})$ & $53.4 \pm 3.66$ \\
Lean mass $(\mathrm{kg})$ & $25.9 \pm 4.2$ & $27.8 \pm 2.7$ & 0.68 & Height & $1.58 \pm 0.05$ \\
Body water & $32.5 \pm 4.9$ & $36.5 \pm 5.1$ & 0.05 & Ideal BMI & 21.5 \\
BMR & $1,461.6 \pm 184.9$ & $1,581.1 \pm 187.6$ & 0.53 & & \\
TEE & $2,101 \pm 314.8$ & $2,099.7 \pm 331.7$ & 0.78 & & \\
\hline
\end{tabular}

aEWLE: Research Project of People with Excess Weight. ${ }^{b}$ EBMSP: Escola Bahiana de Medicina e Saude Publica. ${ }^{*} P$ values obtained through the comparison of initial and final data by means of the Student's $t$-test. Statistical significance level established at $P<0.05$. BMI: body mass index; WC: waist circumference; BMR: baseline metabolic rate; TEE: total energy expenditure.

tional guidance as outpatients. It should be observed that there was a significant reduction in baseline and final values of $\mathrm{WC}$ $(106.0 \pm 12.5 \mathrm{~cm}$ vs. $100.2 \pm 12.5 \mathrm{~cm}, \mathrm{P}=0.003)$, associated to a reduction in the percentage of body fat $(43.23 \pm 7.7 \% \mathrm{vs}$. $40.9 \pm 6.4 \%, \mathrm{P}=0.04)$ and a significant increase in body water $(32.5 \pm 4.9 \mathrm{~kg}$ vs. $36.5 \pm 5.1 \mathrm{~kg}, \mathrm{P}=0.05)$. On the other hand, there was no significant difference between the baseline and final values of weight $(\mathrm{kg}), \mathrm{BMI}\left(\mathrm{kg} / \mathrm{m}^{2}\right)$, lean mass $(\mathrm{kg}), \mathrm{TMB}$ e GET. It should be observed that the average ideal weight (IW) calculated would be $53.4 \pm 3.66 \mathrm{~kg}$, about $32.23 \mathrm{~kg}$ less than the final average weight of the studied group.

Table 4 presents the result of initial clinical data and after 48 months of periodical, regular nutritional guidance, as outpatients. It should be observed that there was a significant decrease in baseline and final values of glycosylated hemoglobin $(7.2 \pm 1.4$ vs. $6.3 \pm 1.2, \mathrm{P}=0.04)$, fasting glycemia $(129.4 \pm$
42.9 vs. $100.3 \pm 22.4, \mathrm{P}=0.05)$. Although no significant difference was observed between the values of total cholesterol $(\mathrm{P}=$ $0.06)$, triglycerides $(\mathrm{P}=0.07)$, HDL $(\mathrm{P}=0.07)$, we observed a difference in LDL-C (126.8 \pm 33.5 vs. $118.9 \pm 30.8, \mathrm{P}=0.04)$.

\section{Discussion}

This prospective study on the treatment of obesity in low income women represents an important contribution for awareness of the physiopathology of nutritional disorders and its treatment in this social group.

It should be observed that the type of obesity of these women is characteristic of central obesity, evidenced by the excessive accumulation of abdominal fat, without mean values of WC of $106 \pm 12.5 \mathrm{~cm}, 22 \mathrm{~cm}$ above the cut-off point of $84 \mathrm{~cm}$ for the

Table 4. Laboratorial Characteristics of Women With Central Obesity Treated at the EWLEa Project at EBMSPb in Salvador, Bahia $(\mathrm{N}=89)$

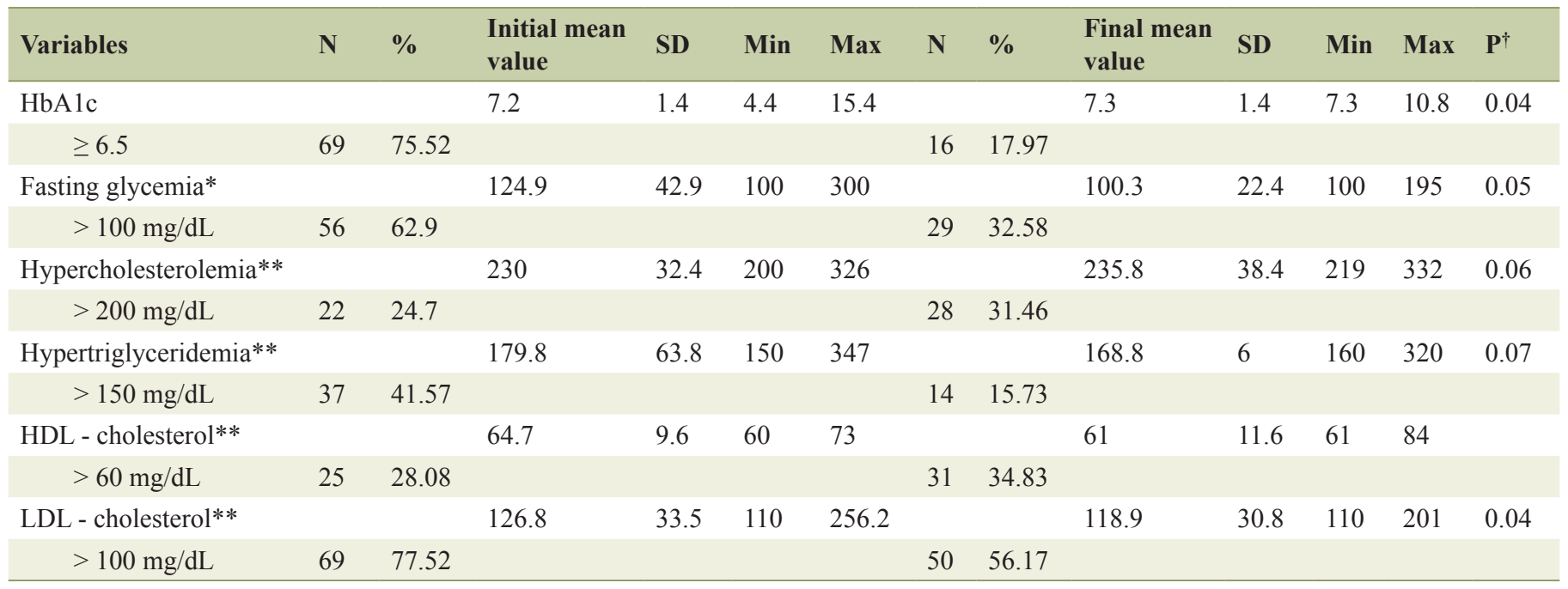

aEWLE: Research Project of People with Excess Weight. 'bBMSP: Escola Bahiana de Medicina e Saude Publica. ${ }^{\dagger} P$ values obtained through the comparison of initial and final data by means of the Student's $t$-test. Statistical significance level established at $P<0.05$. "Brazilian guideline on Dyslipidemia and Prevention of Atherosclerosis (2017). ${ }^{* *}$ Guideline of Brazilian Cardiology Files (2017). 
diagnosis of central obesity in a representative sample of the female population of Salvador city where they also reside [7].

Another important aspect is the association of this type of obesity with low caloric value of the diet, with an average of $1,495.2 \pm 602.5 \mathrm{kcal}$, below the normal average value of $2,000 \mathrm{kcal}$ for active women, with average heights of $1.58 \mathrm{~m}$, represented in this sample. This finding of the association of obesity with a low calorie value of the diet seems to find an explanation in the proportion of the consumption of macronutrients that compose the initially referred basic diet, characterized by an excessive consumption of simple carbohydrates and low consumption of fiber. Accordingly, with the nutritional guidance for adjustments in the consumption to a diet with lower consumption of simple carbohydrates and an increase in the consumption of fibers in a period of accompaniment of 48 months, there was a significant alteration in the body composition, with a reduction in WC $(106 \pm 12.5 \mathrm{~cm}$ to $100.2 \pm$ $11.3 \mathrm{~cm}, \mathrm{P}=0.03)$ and of body fat $(43.23 \pm 7.7 \mathrm{~kg}$ to $40.9 \pm 6.4$ $\mathrm{kg}, \mathrm{P}=0.04)$ associated to an increase in body water $(32.5 \pm$ $4.9 \mathrm{~kg}$ to $36.5 \pm 5.1 \mathrm{~kg}, \mathrm{P}=0.05$ ). This simultaneous increase in body water explains the maintenance of the weight and the BMI, disqualifies the BMI and qualifies WC as specific anthropometric parameter for the diagnosis of central obesity and corroborates with the findings in literature which point out that interventions related to nutritional guidance with women are capable of promoting changes in anthropometric parameters, mainly those related to body mass and WC $[16,17]$.

There is a greater risk of accumulation of intra-abdominal adipose tissue mainly in middle-aged women (40 - 59 years). In this study the highest percentage was identified in this age group $(57.3 \%)$ and it is known that the distribution of fat in the abdominal region is recognized as a risk factor for metabolic disorders and cardiovascular diseases [18]. Apart from this variable, the analysis of other socioeconomic variables, such as ethnicity, schooling and income, as well as its association with anthropometric, clinical and nutritional parameters in detriment of central obesity is of utmost importance, considering the lack of evidence published on such aspects. An example of this is the fact that white and black women, during middle-age, accumulate intra-abdominal adipose tissue in a similar manner, even when there isn't a concomitant significant change in total body fat; nevertheless, there isn't any clear understanding on racial differences in this alteration on a longitudinal level [19]. On an educational level, known to be beneficial to health and capable of producing obesogenic counter-effects through cognitive advantages resulting in healthier life styles, it has received greater attention [20-22].

Low schooling level is a variable that most contributes in literature to associated central obesity, justified by differences in health behaviors, including the consumption of food with better nutritional content, a clearer perception of risks related to the choices of life styles and improved self-control [18].

Du and collaborators [23] suggested that the diet seems to be more important than physical activity to explain the association between education and anthropometric markers of intra-abdominal adipose tissue. The education factor seems to influence the risk of obesity mainly for being associated to the consumption of industrialized food, rich in fat and sugar, nevertheless, in countries in dietary transition, including Brazil, receiving constant inflow of food products, such as processed food with low nutritional values [24]. For this reason the educational level of these women was considered, mainly made up of elementary education $(n=49,54.4 \%)$, followed by incomplete elementary education $(\mathrm{n}=35,38.8 \%)$, based on the hypothesis that a lower period of time spent on education is relatively important for the association between the socioeconomic position and abdominal obesity.

Apart from the relation of these factors which presumably influence the obesogenic life style, others attributes of the socioeconomic position were also considered, such as marital status and income, after all, WC has an inverse association with the socioeconomic position and, particularly in the women assessed; this association was found in Brazilian studies performed in Sao Paulo [25], Goias [26], Maceio [27], Pernambuco [28] and Bahia [29] apart from other temporal analyses in other continents which also evidence an increase in prevalence and incidence of central obesity, associated to reduced socioeconomic situations in the female population, mainly in urban contexts [20-22].

It is recognized that the socioeconomic position influences individual access to goods and services related to food, physical activity and other healthy practices [30], as well as environmental conditions that can interfere in the association between the socioeconomic position and anthropometric parameters. In other words, a healthy standard which is comparable to food ingestion with greater quality tends to standardize anthropometric and clinical parameters. Among the studies that prospectively evaluate the relation of dietary standards and the accumulation of abdominal adipose tissue in an independent manner, Kimokoti and collaborators [31] determined that a high consumption of fat is inversely associated to the development of central obesity. Therefore, our findings corroborate the emerging consensus that the total quality of the diet is important to be considered when preparing strategies for maintaining adhesion to the nutritional treatment; once, even when usual dietary habits are kept without significant difference $(\mathrm{P}>$ $0.05)$, the quality of the diet may be adjusted with nutritional choices and at a cost in accordance with the low income of the women under study.

For Kimokoti and collaborators [31], women who consume a diet with more nutritive food, are less prone to an increase in clinical parameters associated to the development of metabolic diseases, especially waist circumference, than those with lower quality diets. This suggests that interventions to improve empiric dietary standards concentrate on the quality of the diet, may be promissory in terms of preventing the development of future metabolic diseases. Future studies need to consider multiple dietary evaluations, as well as the stability of specific dietary standards of this population and its relation with the anthropometric profile throughout time.

Another factor that could be related to this is the fact that women have a greater reactivity to stimuli related to food than men [32]. According to Luo and collaborators [33], wait circumference, independently of BMI, was positively correlated to the cerebral response to food images of high caloric content, suggesting a connection between the accumulation of abdominal fat and the high brain reward signal. Nevertheless, Bowen and collaborators [34] did not identify a direct relation 
between the diet and abdominal obesity, due to the fact that the effects of the diet on the distribution of body fat are, in reality, the result of cumulative exposure to established standards throughout time, and in particular, the fat becomes more centrally distributed in the measure in which the organism ages.

In the present study there was not any significant difference between the mean baseline value and the final value of the weight $(\mathrm{kg})$, BMI $\left(\mathrm{kg} / \mathrm{m}^{2}\right)$, lean mass $(\mathrm{kg}), \mathrm{BMR}$ and TEE, but considering also the maintenance of weight due to body water, there are accounts that a diet with quality food represents a significant indirect effect on initial weight loss through changes in behavior and health promotion. It is clear that the promotion of healthy behaviors is the most important strategy for a weight loss intervention and other long-term anthropometric, clinical and nutritional parameters [35]. In this context, our findings highlighted a significant mediator of changes in behavior, promoting health, in the path of the diet and a reduction of other important anthropometric measures among the participating women. Finally, the mechanism with which the outpatient care predicts improvement in these variables may be attributable to health promoting behavioral changes.

The mechanisms involving glycemic and lipidic alterations are characterized by a reduced rate of lipolysis and a decreased release of free fat acids (FFA) and proinflammatory adipokines, which consequently reduce the accumulation of intra-abdominal adipose tissue. Such change can contribute towards reducing the risk of developing diseases such as hypertension, hyperglycemia and hypertriglyceridemia, diabetes mellitus, among others [33]. In this regard, abdominal circumference has presented greater correlation with visceral adipose tissue, as compared to other anthropometric assessments for abdominal adiposity, being more informational as based on an underlying biological argument [21].

Therefore, despite the existence of a strong correlation between BMI and central obesity, metabolic alterations are more related to the latter, which, when above recommendation, is diabetogenic, atherogenic, pro-thrombotic and pro-inflamatory [33], for which reason its determination is necessary [36].

The main implication of the results of this study is due to the fact that potential mediators of this relation, such as socioeconomic, clinical and nutritional parameters were jointly explore to better understand their interferences in central obesity.

The lack of measurement of blood pressure is one of the limitations to the development of analysis of the relation among variables, in view that this variable represents an important parameter for the diagnosis of metabolic diseases possibly associated to central obesity.

An important aspect to be discussed refers to the adopted cut-off point to determine abdominal adiposity $(\geq 80 \mathrm{~cm}$ for women; $\geq 94 \mathrm{~cm}$ for men), also used in other studies, guaranteeing greater predictiveness in relation to other cut-off points. Low values in the measure of abdominal circumference (low central adiposity) are a risk for cardiovascular diseases.

\section{Conclusions}

Outpatient care in this study was successful in contributing in a relevant manner towards the reduction of anthropometric measures among the women assessed in the research. This suggests that interventions in relation to dietary standards, concentrated on the quality of the diet should be applied to assist in the prevention of future diseases associated to central obesity.

Hopefully other researches will consider multiple dietary assessments, as well as the stability of specific dietary patters of this public and its relation with the anthropometric profile on a long term.

\section{Financial Disclosure}

This project was financed by FAPESB, by means of a Doctorate Grant for the author.

\section{References}

1. Lear SA, Chockalingam A, Kohli S, Richardson CG, Humphries KH. Elevation in cardiovascular disease risk in South Asians is mediated by differences in visceral adipose tissue. Obesity (Silver Spring). 2012;20(6):12931300.

2. World Health Organization - WHO. Obesity, preventing and managing the global epidemic-report of a WHO consultation on obesity. Geneva: 1998.

3. Mendonca CP, Anjos LAD. Aspectos das praticas alimentares e da atividade fisica como determinantes do crescimento do sobrepeso/obesidade no Brasil. Cadernos de Saude Publica. 2004;20:698-709.

4. Instituto Brasileiro de Geografia e Estatistica - IBGE. Pesquisa de Orcamentos Familiares - POF 20082009. IBGE. 2010. [Acesso em setembro de 2017]. Disponivel em: http:/www.abeso.org.br/uploads/ downloads/71/553a23f27da68.pdf.

5. World Health Organization - WHO. Physical Status. The use and interpretation of anthropometry. Techinical Reports Series 854. Geneva. 1995;44:291-303.

6. Lohman TG, Roche AF. Anthropometric standardization reference manual. Ed. R. Martorell. Champaign: Human kinetics books. 1988;177:3-8.

7. Barbosa PJB, Lessa I, Almeida Filho ND, Magalhaes LBNC, Araujo J. Criterio de obesidade central em populacao brasileira: impacto sobre a sindrome metabolica. Arq Bras Cardiol. 2006; 87(4):407-14.

8. Sociedade Brasileira de Cardiologia - SBC. Departamento de Aterosclerose. IV Diretriz Brasileira de Dislipidemias e Prevencao da Aterosclerose. Arquivos Brasileira Cardiologia. 2007;88(1).

9. Nutrition Data System NDS. Food and nutrient database version 35. Unifesp Regent of University of Minnesota. 2005.

10. NEPA/UNICAMP. Tabela Brasileira de Composicao de Alimentos: Versao 2. [Tabela disponivel online]. NEPA/ UNICAMP, 2006.

11. United States Department of Agriculture (USDA). Agricultural Research Service, 2001.

12. Padovani RM, Amaya-Farfan J, Colugnati FAB, Domene SMA. Dietary reference intakes: aplicabilidade das tab- 
elas em estudos nutricionais. Revista de Nutricao. 2006.

13. Sociedade Brasileira de Cardiologia - SBC. Departamento de Aterosclerose. Atualizacao da Diretriz Brasileira de Dislipidemias e Prevencao da Aterosclerose - 2017. Arquivos Brasileiros de Cardiologia. 2017;109;(2 suppl 1).

14. Sposito AC, Caramelli B, Fonseca FA, Bertolami MC, Afiune NA, Souza AD, et al. IV Brazilian guideline for dyslipidemia and atherosclerosis prevention: Department of Atherosclerosis of Brazilian Society of Cardiology. Arquivos brasileiros de cardiologia. 2007;88(2).

15. SPSS Incoporation. Statical Package for the Social Sciences for Windows student version/SPSS (computer program). Release 13.0. Chicago: Marketing Departament, 2000.

16. Pereira TD, Haraguchi FK. Perfil nutricional dos praticantes de atividades fisicas de um modulo do servico de orientacao ao exercicio (soe) do municipio de Vitoria-ES. Revista Brasileira de Nutricao Esportiva. 2015;9(52):318324.

17. Lopes LC, Lopes-Junior LC, Omena Bomfim E, Silva S, Galvani D, Celia R, et al. Efeitos da atividade fisica na qualidade de vida de mulheres com sobrepeso e obesidade pos-menopausa. Cienc Cuidado Saude. 2014;13(3):439446.

18. Ruiz AJ, Aschner PJ, Puerta MF, Alfonso R. Prevalencia de obesidad abdominal y factores de riesgo asociados en atencion primaria en Colombia. Biomedica (Bogota). 2012;32(4):790-799.

19. Kazlauskaite R, Innola P, Karavolos K, Dugan SA, Avery EF, Fattout Y, Karvonen-Gutierrez C, et al. Abdominal adiposity change in white and black midlife women: The study of women's health across the nation. Obesity (Silver Spring). 2015;23(12):2340-2343.

20. Aitsi-Selmi A, Chen R, Shipley MJ, Marmot MG. Education is associated with lower levels of abdominal obesity in women with a non-agricultural occupation: an interaction study using China's Four Provinces survey. BMC Public Health. 2013;13:769.

21. Alves RFS, Faerstein E. Desigualdade educacional na ocorrencia de obesidade abdominal: Estudo Pro-Saude. Rev Saude Publica. 2015;49(65).

22. Leon-Munoz LM, Gutierrez-Fisac JL, Guallar-Castillon P, Regidor E, Lopez-Garcia E, Martinez-Gomez D, Graciani A, et al. Contribution of lifestyle factors to educational differences in abdominal obesity among the adult population. Clin Nutr. 2014;33(5):836-843.

23. Du P, Wang HJ, Zhang B, Qi SF, Mi YJ, Liu DW, Tian QB. Prevalence of abdominal obesity among Chinese adults in 2011. J Epidemiol. 2017;27(6):282-286.

24. Hernandez E, Perez D, Ortiz-Hernandez L. Consecuencias alimentarias y nutricionales de la inseguridad alimentaria: la perspectiva de madres solteras. Revista chilena de nutricion. 2013;40(4):351-356.
25. Soares MO. Effect of individual nutritional intervention program in food habits and body composition of obese patients/Efeitos de um programa de intervencao nutricional individualizada na composicao corporal e habitos alimentares de paciente obesa. Revista Brasileira de Obesidade, Nutricao e Emagrecimento. 2011;5(25):24-32.

26. Rodrigues APDS, Silveira EAD. Correlacao e associacao de renda e escolaridade com condicões de saude e nutricao em obesos graves. Ciencia \& Saude Coletiva. 2015;20:165-174.

27. Cabral MJ, Vieira KA, Sawaya AL, Florencio TMMT. Perfil socioeconomico, nutricional e de ingestao alimentar de beneficiarios do Programa Bolsa Familia. Estudos avancados. 2013;27(78):71-87.

28. Pinho CPS, Diniz ADS, Arruda IKGD, Batista Filho M, Coelho PC, Sequeira LADS, Lira PICD. Prevalencia e fatores associados a obesidade abdominal em individuos na faixa etaria de 25 a 59 anos do Estado de Pernambuco, Brasil. Cad Saude Publica. 2013;29(2):313-324.

29. Oliveira LCD, West LEM, Araujo EA, Brito JS, Nascimento Sobrinho CL. Prevalencia de adiposidade abdominal em adultos de Sao Francisco do Conde, Bahia, Brasil, 2010. Epidemiologia e Servicos de Saude. 2015;24:135144.

30. Ferreira VA, Magalhaes R. Obesidade entre os pobres no Brasil: a vulnerabilidade feminina. Ciencia \& Saude Coletiva. 2011;16(4):2279-2287.

31. Kimokoti RW, Gona P, Zhu L, Newby PK, Millen BE, Brown LS, D'Agostino RB, et al. Dietary patterns of women are associated with incident abdominal obesity but not metabolic syndrome. J Nutr. 2012;142(9):17201727.

32. Bove RM, White CC, Gerweck AV, Mancuso SM, Bredella MA, Sherman JC, Miller KK. Effect of growth hormone on cognitive function in young women with abdominal obesity. Clin Endocrinol (Oxf). 2016;84(4):635637.

33. Luo S, Romero A, Adam TC, Hu HH, Monterosso J, Page KA. Abdominal fat is associated with a greater brain reward response to high-calorie food cues in Hispanic women. Obesity (Silver Spring). 2013;21(10):2029-2036.

34. Bowen L, Taylor AE, Sullivan R, Ebrahim S, Kinra S, Krishna KV, Kulkarni B, et al. Associations between diet, physical activity and body fat distribution: a cross sectional study in an Indian population. BMC Public Health. 2015;15:281.

35. Choo J, Kang H. Predictors of initial weight loss among women with abdominal obesity: a path model using selfefficacy and health-promoting behaviour. J Adv Nurs. 2015;71(5):1087-1097.

36. Coniglio RI. Relacion entre la obesidad central y los componentes del sindrome metabolico. Acta bioquimica clinica latinoamericana. 2014;48(2):191-201. 